\title{
AMBULATORY BLOOD PRESSURE MEASUREMENT AND ASSESSMENT OF ARTERIAL STIFFNESS IN INDIVIDUALS WITH DIABETES MELLITUS
}

\author{
By \\ Mohammed A. El-Alfy, Ahmed A. El-Mahdy and Abd El-Mohsen M. \\ Abdu \\ Department of Cardiology, Faculty of Medicine, Al-Azhar University, Cairo, Egypt \\ Corresponding author: Mohammed Adel Ahmed El-Alfy \\ E-mail: Alnoaman6@gmail.com
}

\begin{abstract}
Background: Ambulatory BP monitoring (ABPM) might be more accurate than clinical BP measurement. It allows detection of nocturnal BP and dipping patterns, and can reduce false-positive results by detecting white-coat hypertension and false-negative results by detecting masked hypertension.

Objective: Assessing the use of ambulatory BP monitoring (ABPM) in individuals with diabetes mellitus to identify the presence of hypertension and its association with arterial stiffness.

Patients and Methods: The study included 100 diabetic patients in addition to 20 apparently healthy individuals.

Results: In comparison with healthy subjects, patients with diabetes were found to have hypertension using ABPM. ABPM appeared to be useful in the detection of hypertension in patients with diabetes. Comparison between patients and control showed statistically significant difference according to average day, average night and allover average readings. Arterial stiffness also found to be increased in patients with hypertension with statistically significant difference between studied groups according to stiffness index.

Conclusion: ABPM analysis revealed that about one-third of the participants with diabetes had masked hypertension. Those individuals cannot be detected by office BP alone. Moreover, arterial stiffness increased in individuals with masked hypertension. These findings supported the use of ABPM to identify individuals at risk of cardiovascular disease.
\end{abstract}

Key words: Ambulatory blood pressure, Arterial stiffness, Blood pressure patterns, cardiovascular risk, masked hypertension, Nocturnal hypertension, White coat hypertension.

\section{INTRODUCTION}

Hypertension is the major preventable cause of cardiovascular disease (CVD) and all-cause death globally (Banegas et al., 2011). Office BP alone does not reflect the real diurnal $\mathrm{BP}$ variation, and cannot exclude disturbed BP patterns such as masked, nocturnal or white-coat hypertension (Mancia et al., 2015). Therefore, ambulatory BP monitoring (ABPM) might be more accurate than clinical BP measurement. It allows the detection of nocturnal BP and dipping patterns, and can reduce false-positive results by detecting white-coat hypertension and false-negative results by detecting masked hypertension (Solak et 
al., 2016). Several studies have shown the superiority of ABPM over office- or home-based BP monitoring to detect hypertension and predict cardiovascular outcomes (Hodgkinson et al., 2011 and Lazaridis et al., 2015). There is a strong evidence that individuals with masked hypertension have an increased prevalence of target organ damage, more frequently unfavorable metabolic profiles and a higher risk of cardiovascular events than those who are normotensive $\left(O^{\prime}\right.$ Brein et al., 2013). Notably, the prevalence of masked hypertension is higher in individuals with diabetes than in those without, and also higher in individuals treated with antihypertensive than in untreated individuals. This suggests that current treatment regimens may be too focused on normalizing office BP rather than targeting daily BP patterns (Franklin et al., 2013).

Increased arterial stiffness reflects structural and functional changes that precede manifest hypertension and cardiovascular events (George et al., 2015). This phenomenon, known as early vascular ageing, is evident in individuals with diabetes and is associated with elevated BP and vascular complications (Gordin et al., 2011 and Theilade et al., 2013). Very few studies have analyzed the association between masked hypertension and markers of arterial stiffness in individuals with diabetes (Takeno et al., 2012).

The purpose of this study is to assess the use of ambulatory BP monitoring (ABPM) in individuals with diabetes mellitus to identify the presence of hypertension and its association with arterial stiffness.

\section{PATIENTS AND METHODS}

This cross-sectional comparative study involved 100 diabetic patients collected from the Cardiology clinic of Al-Azhar University Hospitals; the patients were screened for the study enrollment prospectively. The study was performed at Cardiology Department, Faculty of Medicine, Al-Azhar University At the period from 1 June 2019 to 15 December 2019.

The protocol and all corresponding documents were approved by Ethical and Research committee, Faculty of Medicine, Al-Azhar University and patients provided informed consents.

A cross-sectional comparative clinically controlled study in which we studied patterns of blood pressure using ABPM and also assessed arterial stiffness in all diabetic selected patients and control.

The patients were classified into two groups matched in age:

Group (1): Patients' group: 100 diabetic patients.

Group (2): Control group: 20 apparently healthy individuals, age and sex matched with the patients' group.

\section{Inclusion criteria:}

The study included patients at any age, with documented diabetes mellitus that were able to understand instructions

\section{Exclusion criteria:}

Hypertensive patients with any type of pulmonary hypertension, patients with congenital heart disease, atrial fibrillation (AF), patients with reduced ejection fraction $\leq 50 \%$, significant comorbidities, 


\section{AMBULATORY BLOOD PRESSURE MEASUREMENT AND ASSESSMENT...}

patients with bad compliance, uncooperative patients, patients that refused the consent or the study or inability to give informed consents.

\section{All patients were subjected to:}

Complete history, general examination, urine analysis and 12 leads ECG.

Ambulatory blood pressure measurement (ABPM) was performed over $24 \mathrm{~h}$ using the Meditech device, which has been validated against invasive and non-invasive reference methods. BP readings were recorded using an upper arm BP cuff (with appropriate cuff size) every 15 min during the day (07:00-22:00 hours) and every 30min at night (22:0007:00 hours). During monitoring, participants were asked to avoid vigorous physical exercise and to keep their arm relaxed. Daytime and night-time periods were defined on the basis of individual sleeping time. At least $70 \%$ of the

measurements had to be valid, and monitoring had to cover at least $20 \mathrm{~h}$, with an interval of no longer than $3 \mathrm{~h}$ between two successive readings

\section{Statistical analysis:}

Data were analyzed using Statistical Program for Social Science (SPSS) version 15.0. Quantitative data were expressed as mean \pm standard deviation (SD). Qualitative data were expressed as frequency and percentage.

\section{The following tests were done:}

Mann-Whitney U test was used when comparing between two means (for abnormal distributed data).

Chi-square test was used when comparing between non-parametric data.

P-value $<0.05$ was considered significant.

\section{RESULTS}

No statistical significant difference between studied groups as regard personal data, i.e age, sex and smoking (Table 1).

Table (1): Comparison between studied groups as regard personal data

\begin{tabular}{|c|c|c|c|c|c|}
\hline \multicolumn{2}{|c|}{$\begin{array}{ll}\text { Parameters } & \text { Groups }\end{array}$} & \multirow{2}{*}{$\begin{array}{c}\begin{array}{c}\text { Control } \\
(\mathbf{N}=\mathbf{2 0})\end{array} \\
42.2 \pm 11.1 \\
\end{array}$} & \multicolumn{2}{|c|}{$\begin{array}{l}\text { Patients } \\
(N=100)\end{array}$} & P-value \\
\hline \multirow{2}{*}{$\begin{array}{l}\text { Age } \\
\text { (years) }\end{array}$} & Mean \pm SD & & & 13.2 & \multirow{2}{*}{0.098} \\
\hline & Median & 43.5 & & & \\
\hline \multirow{2}{*}{$\begin{array}{l}\text { Sex } \\
(\text { No \& \%) }\end{array}$} & Male & $40 \%$ & 48 & $48 \%$ & \multirow{2}{*}{0.513} \\
\hline & Female & $1260 \%$ & 52 & $52 \%$ & \\
\hline \multirow{2}{*}{$\begin{array}{l}\text { Smoking } \\
(\text { No \& \%) }\end{array}$} & $\begin{array}{l}\text { Non } \\
\end{array}$ & $70 \%$ & 73 & $73 \%$ & \multirow{2}{*}{0.784} \\
\hline & Smoker & $30 \%$ & 27 & $27 \%$ & \\
\hline
\end{tabular}

As regard duration of $\mathrm{DM}$, the mean duration was $5.8 \pm 3.5$ years with minimum duration of 1 year and maximum duration of 15 years. As regard type of DM, there were 42 patients $(42 \%)$ of type I DM and 58 patients $(58 \%)$ of type II DM (Table 2). 
Table (2): Description of disease data in patients group

\begin{tabular}{|l|l|r|r|}
\hline \multirow{2}{*}{ Parameters } & \multicolumn{2}{c|}{ Patients } & \multicolumn{2}{|c|}{$(\mathbf{N}=\mathbf{1 0 0})$} \\
\hline $\begin{array}{l}\text { Duration of DM } \\
\text { (years) }\end{array}$ & Mean \pm SD & \multicolumn{2}{|c|}{$5.8 \pm 3.5$} \\
\cline { 2 - 4 } Type of DM & Min - max & \multicolumn{2}{|c|}{$1-15$} \\
\hline & Type I & 42 & $42 \%$ \\
\cline { 2 - 4 } & Type II & 58 & $58 \%$ \\
\hline
\end{tabular}

There was a statistically significant difference between studied groups as regard ambulatory blood pressure (Table 3).

Table (3): Comparison between studied groups as regard ambulatory blood pressure

\begin{tabular}{|c|c|c|c|c|c|}
\hline \multicolumn{3}{|c|}{$\begin{array}{ll}\begin{array}{l}\text { Ambulatory } \\
\text { blood pressure }\end{array} & \text { Groups } \\
\end{array}$} & $\begin{array}{l}\text { Control } \\
(\mathbf{N}=\mathbf{2 0})\end{array}$ & $\begin{array}{l}\text { Patients } \\
(\mathbf{N}=100)\end{array}$ & P-value \\
\hline \multirow{4}{*}{ 离 } & \multirow{2}{*}{$\begin{array}{c}\text { SBP } \\
(\mathbf{m m H g})\end{array}$} & Mean \pm SD & $119.3 \pm 9.4$ & $131.4 \pm 19.5$ & \multirow{2}{*}{0.021} \\
\hline & & Median & 120 & 125.5 & \\
\hline & \multirow{2}{*}{$\begin{array}{c}\text { DBP } \\
(\mathbf{m m H g})\end{array}$} & Mean \pm SD & $73.5 \pm 7.04$ & $81.4 \pm 13.1$ & \multirow{2}{*}{0.021} \\
\hline & & Median & 73.5 & 78 & \\
\hline \multirow{4}{*}{ 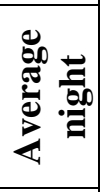 } & \multirow{2}{*}{$\begin{array}{c}\text { SBP } \\
(\mathrm{mmHg})\end{array}$} & Mean \pm SD & $102.7 \pm 6.2$ & $116 \pm 19.6$ & \multirow{2}{*}{0.012} \\
\hline & & Median & 102.5 & 108.5 & \\
\hline & \multirow{2}{*}{$\begin{array}{c}\text { DBP } \\
(\mathbf{m m H g})\end{array}$} & Mean \pm SD & $62.4 \pm 3.9$ & $70.6 \pm 11.9$ & \multirow{2}{*}{0.009} \\
\hline & & Median & 62 & 66 & \\
\hline \multirow{4}{*}{ 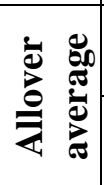 } & \multirow{2}{*}{$\begin{array}{c}\text { SBP } \\
(\mathbf{m m H g})\end{array}$} & Mean \pm SD & $111.5 \pm 7.3$ & $124.01 \pm 19.4$ & \multirow{2}{*}{0.021} \\
\hline & & Median & 112 & 117.5 & \\
\hline & \multirow{2}{*}{$\begin{array}{c}\text { DBP } \\
(\mathbf{m m H g})\end{array}$} & Mean \pm SD & $67.9 \pm 4.9$ & $76.2 \pm 12.3$ & \multirow{2}{*}{0.01} \\
\hline & & Median & 67.8 & 72 & \\
\hline
\end{tabular}

There was a statistically significant difference between studied groups as regard stiffness index (Table 4).

Table (4): Comparison between studied groups as regard Stiffness Index.

\begin{tabular}{|c|c|c|c|c|c|}
\hline $\begin{array}{ll}\text { Stiffness index } & \text { Groups } \\
\end{array}$ & \multicolumn{2}{|c|}{$\begin{array}{l}\text { Control } \\
(\mathrm{N}=20)\end{array}$} & \multicolumn{2}{|c|}{$\begin{array}{l}\text { Patients } \\
(\mathrm{N}=100)\end{array}$} & P-value \\
\hline Mean \pm SD & \multicolumn{2}{|c|}{$0.59 \pm 0.1$} & \multicolumn{2}{|c|}{$0.5 \pm 0.12$} & \multirow{2}{*}{0.012} \\
\hline Median & \multicolumn{2}{|c|}{0.6} & \multicolumn{2}{|c|}{0.5} & \\
\hline Negative & 20 & $100 \%$ & 66 & $66 \%$ & \\
\hline Positive & \multicolumn{2}{|c|}{$0 \%$} & 34 & $34 \%$ & .002 \\
\hline
\end{tabular}

Statistical significances were noted between stiffness index and age, sex, smoking, duration of diabetes and type of diabetes (Table 5). 


\section{AMBULATORY BLOOD PRESSURE MEASUREMENT AND ASSESSMENT...}

Table (5): Relation between stiffness index and other studied data in patients group

\begin{tabular}{|c|c|c|c|c|c|c|}
\hline \multicolumn{2}{|c|}{$\begin{array}{l}\text { Stiffness Index } \\
\text { Personal data }\end{array}$} & \multicolumn{2}{|c|}{$\begin{array}{c}\text { Negative } \\
(n=66)\end{array}$} & \multicolumn{2}{|c|}{$\begin{array}{l}\text { Positive } \\
(\mathbf{n}=\mathbf{3 4})\end{array}$} & P-value \\
\hline \multirow{2}{*}{ Age (years) } & Mean \pm SD & \multicolumn{2}{|c|}{$43 \pm 11.5$} & \multicolumn{2}{|c|}{$56.3 \pm 11.9$} & \multirow{2}{*}{$<0.001$} \\
\hline & Median & \multicolumn{2}{|c|}{44} & \multicolumn{2}{|c|}{57} & \\
\hline \multirow{2}{*}{ Sex } & Male & 24 & $36.4 \%$ & 24 & $70.6 \%$ & \multirow[t]{2}{*}{0.001} \\
\hline & Female & 42 & $63.6 \%$ & 10 & $29.4 \%$ & \\
\hline \multirow{2}{*}{ Smoking } & Non & 62 & $93.9 \%$ & 11 & $32.4 \%$ & \multirow[t]{2}{*}{$<0.001$} \\
\hline & Smoker & 4 & $6.1 \%$ & 23 & $67.6 \%$ & \\
\hline \multirow{2}{*}{$\begin{array}{l}\text { DM duration } \\
\text { (years) }\end{array}$} & Mean \pm SD & \multicolumn{2}{|c|}{$4.4 \pm 2.3$} & \multicolumn{2}{|c|}{$8.6 \pm 3.4$} & \multirow[t]{2}{*}{$<0.001$} \\
\hline & Median & \multicolumn{2}{|c|}{-} & \multicolumn{2}{|c|}{9} & \\
\hline \multirow{2}{*}{ Type of DM } & Type I & 34 & $51.5 \%$ & 8 & $23.5 \%$ & \multirow[t]{2}{*}{0.007} \\
\hline & Type II & 32 & $48.5 \%$ & 26 & $76.5 \%$ & \\
\hline
\end{tabular}

There were statistical significant relation between stiffness index and blood

pressure (SBP \& DBP) in patients group (Table 6).

Table (6): Relation between stiffness index and blood pressure in patients groups

\begin{tabular}{|c|c|c|c|c|c|}
\hline \multicolumn{2}{|c|}{ Blood pressure } & Stiffness Index & $\begin{array}{c}\begin{array}{c}\text { Negative } \\
(n=66)\end{array} \\
\end{array}$ & $\begin{array}{l}\text { Positive } \\
(\mathrm{n}=34)\end{array}$ & \multirow{3}{*}{$\begin{array}{l}\text { P-value } \\
\mathbf{0 . 0 0 1}\end{array}$} \\
\hline \multirow{4}{*}{ 商 } & \multirow{2}{*}{$\begin{array}{c}\text { SBP } \\
(\mathbf{m m H g})\end{array}$} & Mean \pm SD & $116.2 \pm 7.4$ & $137.6 \pm 5.9$ & \\
\hline & & Median & 115 & 135 & \\
\hline & \multirow{2}{*}{$\begin{array}{c}\text { DBP } \\
(\mathbf{m m H g})\end{array}$} & Mean \pm SD & $71.9 \pm 6.5$ & $86.8 \pm 5.3$ & \multirow{2}{*}{$<0.001$} \\
\hline & & Median & 70 & 87.5 & \\
\hline \multirow{4}{*}{ 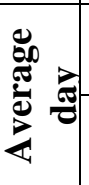 } & \multirow{2}{*}{$\begin{array}{c}\text { SBP } \\
(\mathbf{m m H g})\end{array}$} & Mean \pm SD & $119.4 \pm 9.03$ & $155.2 \pm 10.3$ & \multirow{2}{*}{$<0.001$} \\
\hline & & Median & 119 & 154.5 & \\
\hline & \multirow{2}{*}{$\begin{array}{c}\text { DBP } \\
(\mathrm{mmHg})\end{array}$} & Mean \pm SD & $74.3 \pm 7.8$ & $95.4 \pm 9.2$ & \multirow{2}{*}{$<0.001$} \\
\hline & & Median & 73 & 94 & \\
\hline \multirow{4}{*}{ 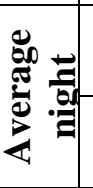 } & \multirow{2}{*}{$\begin{array}{c}\text { SBP } \\
(\mathbf{m m H g})\end{array}$} & Mean \pm SD & $103.9 \pm 8.3$ & $139.5 \pm 12.6$ & \multirow{2}{*}{$<0.001$} \\
\hline & & Median & 101 & 136.5 & \\
\hline & \multirow{2}{*}{$\begin{array}{c}\text { DBP } \\
(\mathrm{mmHg})\end{array}$} & Mean \pm SD & $63.8 \pm 6.9$ & $83.8 \pm 7.9$ & \multirow{2}{*}{$<0.001$} \\
\hline & & Median & 63 & 83 & \\
\hline \multirow{4}{*}{ 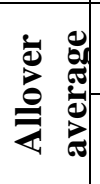 } & \multirow{2}{*}{$\begin{array}{c}\text { SBP } \\
(\mathbf{m m H g})\end{array}$} & Mean \pm SD & $111.7 \pm 8.2$ & $147.9 \pm 10.7$ & \multirow{2}{*}{$<0.001$} \\
\hline & & Median & 111 & 146 & \\
\hline & \multirow{2}{*}{$\begin{array}{c}\text { DBP } \\
(\mathrm{mmHg})\end{array}$} & Mean \pm SD & $69.04 \pm 6.9$ & $89.9 \pm 7.9$ & \multirow{2}{*}{$<0.001$} \\
\hline & & Median & 68 & 89 & \\
\hline
\end{tabular}

\section{DISCUSSION}

Duration of diabetes was $5.8 \pm 3.5$ years with minimum duration of 1 year and maximum duration of 15 years. $42 \%$ was type I DM, and 58\% was type II DM.

Our results showed a potential benefit of the parallel use of office BP and ABPM to identify individuals who are at risk, and thereby those who would not have been detected by office BP alone.

Arterial stiffness was greater in individuals with masked hypertension, compared with truly normotensive individuals.

This is in agreement with the findings of Laugesen et al. (2009) who studied arterial ABPM in T1DM versus control. 
Gunawan et al. (2019) showed contrary findings in sub analysis of T2DM none hypertensive. This difference could be due to race, geographic region or number of patients involved in the studies.

Rodrigues et al. (2010) reported that the occurrence of masked hypertension in diabetic patients who were not taking antihypertensive medication was approximately $7 \%$ in the entire cohort and about $14 \%$ among those with normal office BP. Moreover, nearly $23 \%$ of those with normal office BP had nocturnal hypertension.

In a Spanish study of normotensive individuals with diabetes, the prevalence of masked hypertension was $24 \%$ (MateoGavira et al., 2016).

The population-based International Database on Ambulatory blood pressure monitoring in relation to Cardiovascular Outcomes (IDACO) study showed that masked hypertension is more common in individuals with diabetes (Franklin et al., 2013). About $6 \%$ of the middle-aged or the elderly participants had diabetes, but there was no distinction made between diabetes types, suggesting that the majority might have had type 2 diabetes. Among those who had normal office BP, the prevalence of masked hypertension was $29 \%$ in those who had diabetes, while it was $19 \%$ in non-diabetic individuals. The definition of masked hypertension was based on daytime ABPM (threshold $\geq 135 / 85 \mathrm{mmHg}$ ).

As recommended by the European Society of Hypertension guidelines (Parati et al., 2014). Our definition of masked hypertension was based on $24 \mathrm{~h}$ ABPM rather than daytime ABPM.
By using daytime ABPM alone, we would have missed many of those affected. Consequently, in our study, the prevalence of masked hypertension was $34 \%$ which is higher than that of IDACO study and this can be explained to some extent due to the use of day time measurements in IDACO study.

Only a few small studies have assessed the prevalence of masked and nocturnal hypertension in individuals with diabetes (Rodrigues et al., 2010 and Mateo-Gavira et al., 2016).

\section{CONCLUSION}

One-third of participants had masked hypertension, and the same group had also signs of arterial stiffness, a condition known to precede manifest hypertension and cardiovascular disease. Therefore, detailed evaluation of BP patterns by ABPM could be clinically meaningful in order to improve the diagnosis and management of hypertension in this group.

\section{REFERENCES}

1. Banegas JR, Lopez-Garcia E, Dallongeville J, Guallar E, Halcox JP, Borghi C, MassoGonzalez EL, Jimenez FJ, Perk J, Steg PG, De Backer $G$ and Rodriguez- Artalejo F (2011): Achievement of treatment goals for primary prevention of cardiovascular disease in clinical practice across Europe: the EURIKA study. Eur Heart J., 32:2143-2152.

2. Franklin, S. S., Thijs, L., Li, Y., Hansen, T. W., Boggia, J., Liu, Y. and Torp-Pedersen, C. (2013): Masked hypertension in diabetes mellitus: treatment implications for clinical practice. Hypertension, 61(5): 964-971.

3. George B, Bantwal G, Ayyar V and Mathew V (2015): Occurrence of increased arterial stiffness in a cohort of adult patients with type 1 diabetes mellitus when compared 


\section{AMBULATORY BLOOD PRESSURE MEASUREMENT AND ASSESSMENT...}

to normoglycemic con- trols. J Diabetes Sci Technol., 9:138-144

4. Gordin, D., Wadén, J., Forsblom, C., Thorn, L., Rosengård-Bärlund, M., Tolonen, N. and FinnDiane Study Group. (2011): Pulse pressure predicts incident cardiovascular disease but not diabetic nephropathy in patients with type 1 diabetes (The FinnDiane Study). Diabetes Care, 34(4): 886-891.

5. Gunawan, F., Ng, H. Y., Gilfillan, C. and Anpalahan, M. (2019): Ambulatory Blood Pressure Monitoring in Type 2 Diabetes Mellitus: A Cross-sectional Study. Current Hypertension Reviews, 15(2): 135-143.

6. Hodgkinson, J., Mant, J., Martin, U., Guo, B., Hobbs, F. D. R., Deeks, J. J. and McManus, R. J. (2011): Relative effectiveness of clinic and home blood pressure monitoring compared with ambulatory blood pressure monitoring in diagnosis of hypertension: systematic review. BMJ, 342, d3621.

7. Laugesen, E., Hansen, K. W., Knudsen, S. T., Erlandsen, M., Ebbehøj, E., Mogensen, C. E. and Poulsen, P. L. (2009): Increased ambulatory arterial stiffness index and pulse pressure in microalbuminuric patients with type 1 diabetes. American Journal of Hypertension, 22(5): 513-519.

8. Lazaridis, A. A., Sarafidis, P. A. and Ruilope, L. M. (2015): Ambulatory blood pressure monitoring in the diagnosis, prognosis, and management of resistant hypertension: still a matter of our resistance? Current Hypertension Reports, 17(10): 78.

9. Mancia $G$ and Verdecchia $P$ (2015): Clinical value of ambulatory blood pressure: evidence and limits. Circ Res., 116:10341045.

10. Mateo-Gavira, I., Vílchez-López, F. J., García-Palacios, M. V., Carral-San Laureano, F., Jiménez-Carmona, S. and Aguilar-Diosdado, M. (2016): Nocturnal blood pressure is associated with the progression of microvascular complications and hypertension in patients with type 1 diabetes mellitus. Journal of Diabetes and its Complications, 30(7): 1326-1332.

11. O'Brien, E., Parati, G., Stergiou, G. S., Asmar, R. P., Beilin, L. and Bilo, G. (2013): Erratum: European society of hypertension position paper on ambulatory blood pressure monitoring (Journal of Hypertension (2013) 31 (1731-1768)). Journal of Hypertension, 31(12): 2467.

12. Parati, G., Stergiou, G., O'Brien, E., Asmar, R., Beilin, L., Bilo, G. and Fagard, R. (2014): European Society of Hypertension practice guidelines for ambulatory blood pressure monitoring. Journal of Hypertension, 32(7): 1359-1366.

13. Rodrigues, T. C., Canani, L. H., Viatroski, R. S., Hoffmann, L. H., Esteves, J. F. and Gross, J. L. (2010): Masked hypertension, nocturnal blood pressure and retinopathy in normotensive patients with type 1 diabetes. Diabetes Research and Clinical Practice, 87(2): 240-245.

14. Solak, Y., Kario, K., Covic, A., Bertelsen, N., Afsar, B., Ozkok, A. and Kanbay, M. (2016): Clinical value of ambulatory blood pressure: Is it time to recommend for all patients with hypertension?. Clinical and Experimental Nephrology, 20(1): 14-22.

15. Takeno, K., Mita, T., Nakayama, S., Goto, H., Komiya, K., Abe, H. and Kawamori, R. (2012): Masked hypertension, endothelial dysfunction, and arterial stiffness in type 2 diabetes mellitus: a pilot study. American Journal of Hypertension, 25(2): 165-170.

16. Theilade S, Lajer M, Persson F, Joergensen $C$ and Rossing $P$ (2013): Arterial stiffness is associated with cardiovascular, renal, retinal, and autonomic disease in type1 diabetes. Diabetes Care, $36: 715-721$ 


\section{قياس ضفط اللدم بواسطة جهاز ضفط اللدم المتنقل وتقييم تصلب

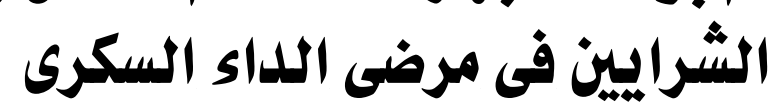

محمد عادل أحمد الألفى، أحمد عبدالؤوف المهذى، عبدالمحسن مصطفى عبده قسم القلب، كلية الطب، جامعة الأزهر

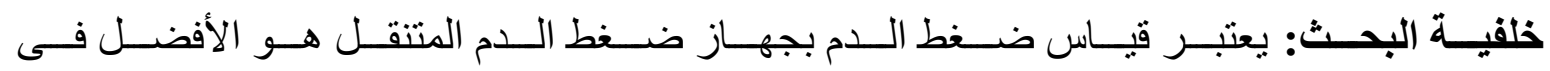

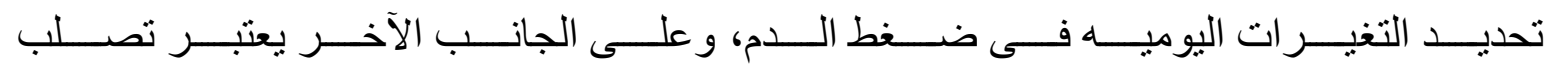

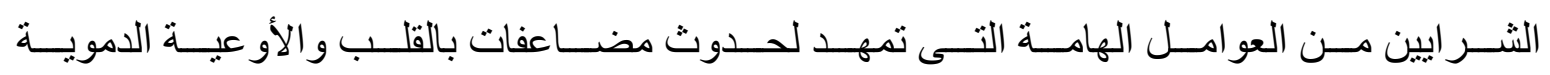

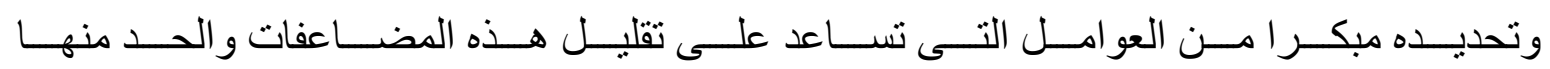
مبكر ا.

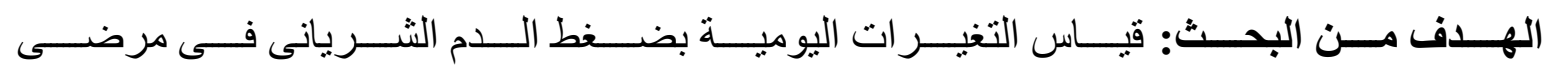

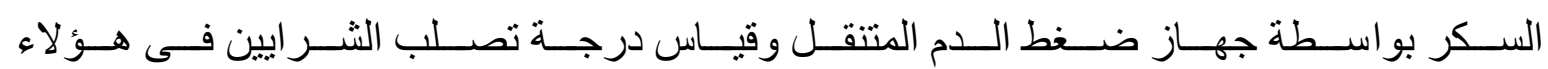
المرضى.

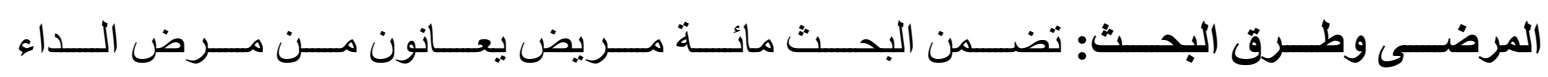

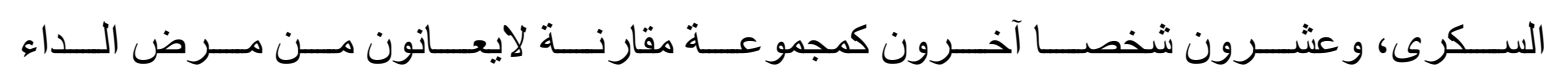

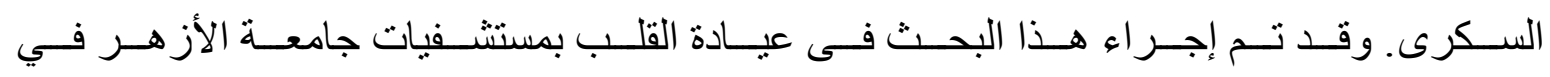

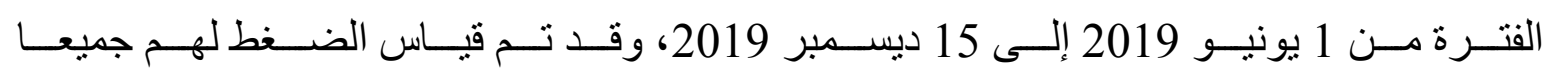

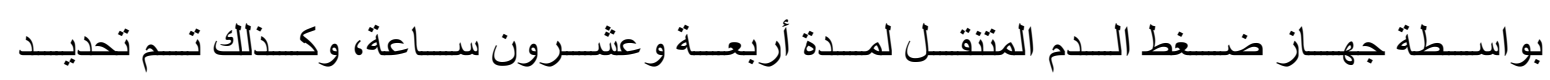
نسب تصلب الثر ايين بو اسطة عامل التصلب الثريانى.

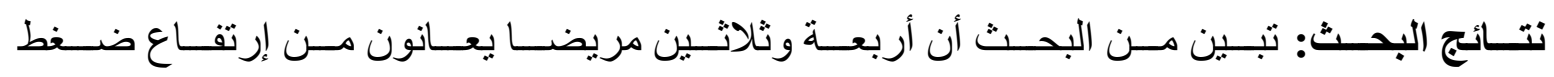
الدم الشريانى وكذلك من إرتفاع نسبة التصلب الثريانى بهر.

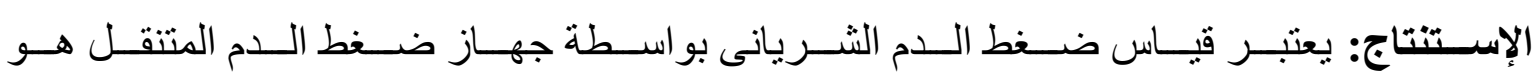

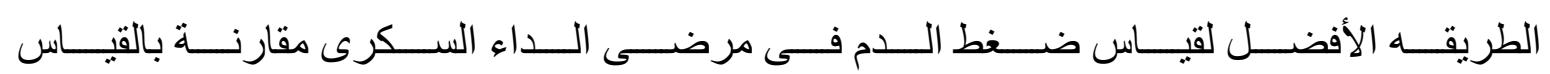
المكتبى. 